\title{
Acute brachial diparesis
}

\author{
Revelino Lopes, ${ }^{1}$ Hipólito Nzwalo, ${ }^{2}$ Luis Malaia, ${ }^{1}$ Fátima Ferreira ${ }^{2}$
}

'Department of Physical Medicine and Rehabilitation, Faro Hospital, EPE, Faro,

Portugal

${ }^{2}$ Department of Neurology, Faro Hospital, EPE, Faro, Portugal

\section{Correspondence to}

Dr Hipólito Nzwalo,

nzwalo@gmail.com
To cite: Lopes $\mathrm{R}$, Nzwalo $\mathrm{H}$, Malaia L, et al. BMJ Case Rep Published online:

[please include Day Month Year] doi:10.1136/bcr-2013200476

\section{DESCRIPTION}

A 66-year-old man was brought to the hospital after an episode of binge drinking, in which he was found in an unusual position (both arms trapped between the toilet and the sink). During extraction, his son used different manoeuvres, including traction, abduction and flexion of the arms. Muscle strength was reduced, and sensitivity and myotatic reflexes were altered in the upper limbs (table 1).

Table 1 Neurological findings in the upper limbs at diagnosis, and following rehabilitation

\begin{tabular}{|c|c|c|c|c|}
\hline & Right & Left & Right & Left \\
\hline & \multicolumn{2}{|l|}{ At diagnosis } & \multicolumn{2}{|c|}{ Following rehabilitation (6 months) } \\
\hline \multicolumn{5}{|l|}{ Motor examination } \\
\hline Shoulder abduction & 1 & 3 & 2 & 4 \\
\hline Shoulder flexion & 0 & 3 & 2 & 4 \\
\hline Elbow extension & 0 & 2 & 2 & 4 \\
\hline Elbow flexion & 0 & 2 & 2 & 4 \\
\hline Wrist extension & 0 & 2 & 2 & 4 \\
\hline Wrist flexion & 0 & 1 & 2 & 4 \\
\hline Finger extension & 0 & 1 & 1 & 4 \\
\hline Finger flexion & 0 & 1 & 1 & 4 \\
\hline \multicolumn{5}{|c|}{ Absence of clinical limitation of scapula elevation and rotation/ no scapula alata } \\
\hline \multicolumn{5}{|l|}{ Sensory examination } \\
\hline Pain and touch sense & Absent (C5-T1) & Reduced (C6-C8) & Reduced* $^{*}$ (C5-T1) & Reduced (C6-C8) \\
\hline Position and vibratory sense & Absent & Normal & Reduced & Normal \\
\hline Myotatic reflexes & Absent & Absent & Reduced & Reduced \\
\hline
\end{tabular}

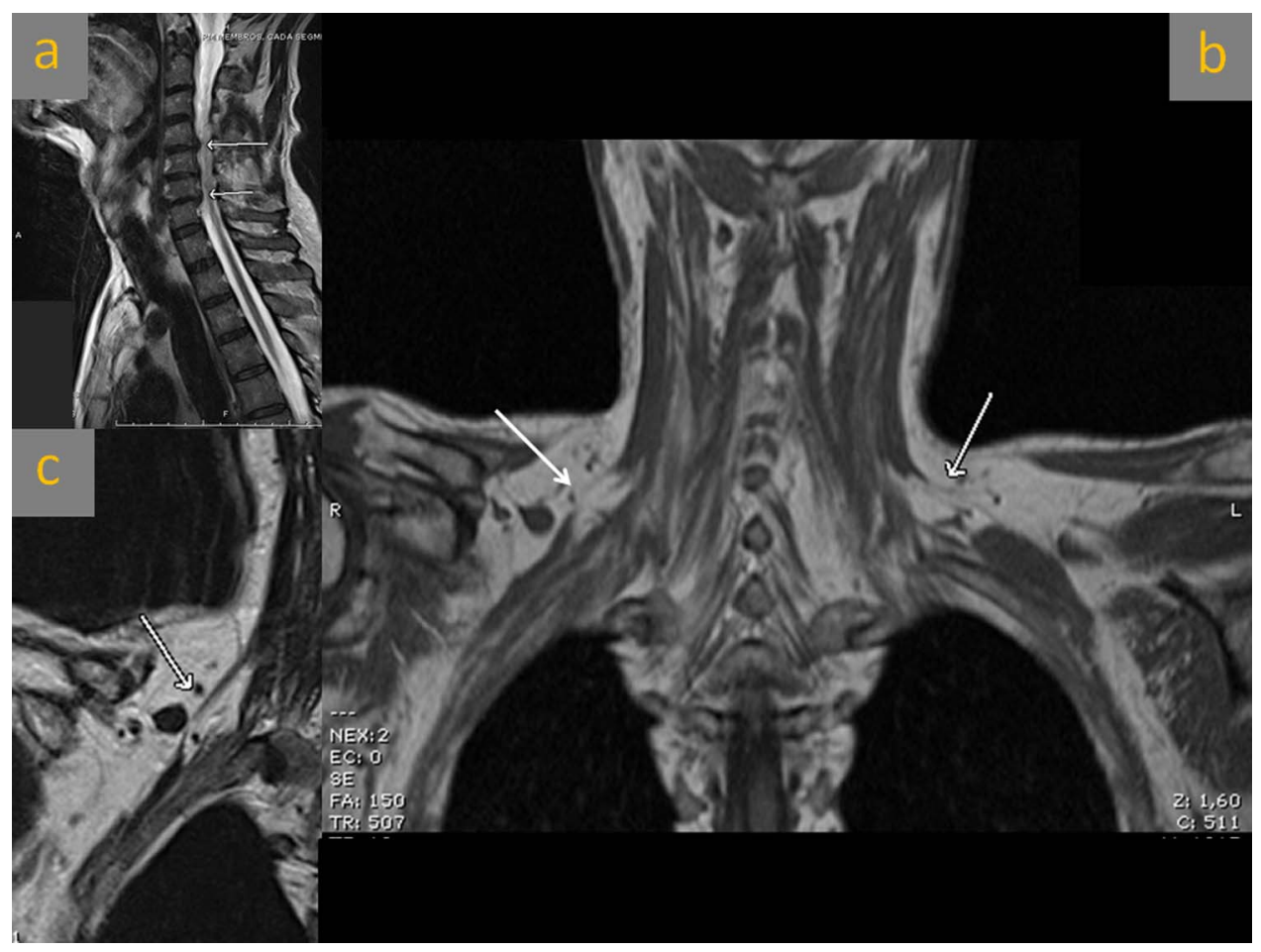

Figure 1 (A) Cervical MRI showing moderate degenerative changes, moulding of the subarachnoid space at C5-C6 and C6-C7 (arrows), without any sign of spinal cord lesion; (B) Short tau inversion recovery imaging showing bilateral hyperintense, enlarged trunks (arrows) compatible with postganglionic brachial plexus lesion (axonotmesis or neurotmesis); (C) Amplified image of plexus injury (right side). 
The lower limb examination was normal. Although cervical MRI showed only moderate degenerative disease (figure 1A), the clinical manifestations were attributed to spinal shock/acute traumatic central cord syndrome. No improvement was observed after 2 weeks, raising suspicions of bilateral brachial plexopathy (BBP), shown in the plexus MRI (figure 1B,C). The presence 4 weeks later on electrodiagnostic testing (in different nerves or muscles) of fibrillation; positive sharp waves; decrease/ absent compound muscle action potential amplitude; decrease/ absent sensory nerve action potential; and nerve conduction blocks, confirmed the diagnosis. Partial recovery occurred with intensive rehabilitation (table 1). BBP is extremely rare in adults. The main causes are postoperative paralysis, and severe traumatic accidents. ${ }^{1} 2$ In our case, the history, the bilateralism and the absence of symptoms such as pain, paresthesias, made these diagnosis very unlikely. In an appropriate context, brachial plexus MRI is sensitive, and highly specific for the diagnosis of traumatic brachial lesions. ${ }^{1} 2$ However, electromyography remains as the diagnostic gold standard. ${ }^{1}$ Restoring of strength through collateral reinnervation over time is a possibility. Surgical intervention depends on the lesion severity and degree of recovery during the first 6 months. ${ }^{3}$

\section{Learning points}

- Brachial plexus lesions should be considered in any differential diagnosis of limb paresis.

- In rare cases, acute bilateral brachial plexopathy occurs outside the usual clinical settings, such as severe traumatic accidents or, in postoperative paralysis.

- Intensive rehabilitation potentially improves functional outcome in cases of brachial plexopathy.

Contributors RL and HN designed and wrote the manuscript; LM and FF revised the manuscript. All authors read and approved the final version of the manuscript.

Competing interests None.

Patient consent Obtained.

Provenance and peer review Not commissioned; externally peer reviewed.

\section{REFERENCES}

1 Wilbourn AJ. Brachial plexus lesions. In: Dyck PJ, Thomas PK, eds. Peripheral neuropathy, Vol 2. 4th edn. Philadelphia, PA: W B Saunders, 2005:1339-73.

2 Bilbey JH, Lamond RG, Mattrey RF. MR imaging of disorders of the brachial plexus. J Magn Reson Imaging 1994;4:13-18.

3 Belzberg AJ, Dorsi MJ, Storm PB, et al. Moriarity, surgical repair of brachial plexus injury: a multinational survey of experienced peripheral nerve surgeons. J Neurosurg 2004;3:365-76.

Copyright 2013 BMJ Publishing Group. All rights reserved. For permission to reuse any of this content visit

http://group.bmj.com/group/rights-licensing/permissions.

BMJ Case Report Fellows may re-use this article for personal use and teaching without any further permission.

Become a Fellow of BMJ Case Reports today and you can:

- Submit as many cases as you like

- Enjoy fast sympathetic peer review and rapid publication of accepted articles

- Access all the published articles

- Re-use any of the published material for personal use and teaching without further permission

For information on Institutional Fellowships contact consortiasales@bmjgroup.com

Visit casereports.bmj.com for more articles like this and to become a Fellow 